\title{
DIGITAL MARKETING UNTUK USAHA MIKRO KECIL MENENGAH (Studi Kasus Pada Coffeestrip Bandung)
}

\author{
Centurion Chandratama Priyatna, F.X Ari Agung Prastowo dan Fajar Syuderajat \\ Universitas Padjadjaran \\ E-mail: centurion.priyatna@unpad.ac.id
}

\begin{abstract}
ABSTRAK. Sejak adanya pandemi COVID-19 pada saat ini, beberapa pengusaha mulai mencari jalan untuk menjual produk mereka dikarenakan beberapa lini bisnis tidak dapat beroperasi secara maksimal jika secara offline. Maka mereka melakukan bisnis digital, hal ini merupakan salah satu hal yang paling diminati di bidang ekonomi yang dilakukan untuk memperluas market share perusahaan dalam bisnis mereka secara online. Dari beberapa kategori bisnis di Indonesia, Usaha Mikro, Kecil dan Menengah atau (UMKM) merupakan salah satu kategori bisnis yang mendapatkan dampak paling besar dari pandemi COVID-19, dikarenakan keuangan dari pelaku bisnis kategori UMKM beberapa bahkan belum stabil sebelum adanya pandemi COVID-19 dan makin diperparah dengan adanya pandemi tersebut. Maka dari itu kami membantu salah satu UMKM di Bandung yaitu Coffeestrip, melalui pengurusan media sosial dengan merencanakan konten, foto produk, desain feeds Instagram, menulis caption, dan mengunggah konten. Semuanya dilakukan pada media sosial instagram Coffeestrip. Selain itu dilakukan juga pembuatan media platform marketplace (Shopee) dan on-demand multi-service platform (Gojek) untuk meningkatkan penjualan dari bisnis UMKM tersebut
\end{abstract}

Kata Kunci: Digital marketing; online; pengusaha; UMKM

ABSTRACT. Since the current COVID-19 pandemic, some entrepreneurs have started looking for ways to sell their products because some business lines cannot optimally operate offline, so they switch to digital business. Digital marketing is one of the most popular things in the economic sector to expand its market share online. Out of several business categories in Indonesia, Micro, Small, and Medium Enterprises or (MSMEs) are one of the business categories that have the most significant impact from the COVID-19 pandemic because the finances of some of the MSME category businesses were not even stable before the COVID-19 pandemic, and worsened by the pandemic. Therefore, the community service is done by helping one of the MSMEs in Bandung, namely Coffeestrip, by managing its social media through planning content, product photos, designing Instagram feeds, writing captions, and uploading content. The project is done on the Instagram platform of Coffeestrip. Additionally, the project also creates a Coffeestrip account on the marketplace (Shopee), and an on-demand multi-service platform (Gojek) in increasing sales from the MSME business.

Keywords: Digital marketing; online; entrepreneurs; UMKM

\section{PENDAHULUAN}

Industri kreatif adalah salah satu industri yang sedang menjadi primadona di Indonesia. Industri ini menghasilkan revenue yang cukup besar. Triawan Munaf, Kepala Badan Ekonomi dan Kreatif (Bekraf), di tahun 2018, mengatakan bahwa pendapatan sektor ekonomi kreatif (ekraf) tahun 2016 tercatat Rp922,59 triliun atau naik menjadi $7,44 \%$ terhadap total PDB nasional. Berdasarkan outlook ekonomi kreatif 2019 nilai PDB ekraf pada 2017, 2018, dan 2019, diprediksikan masing-masing Rp1.009 triliun, Rp1.105 triliun, dan Rp1.211 triliun (Fuad, 2018). Prospek pendapatan yang cukup tinggi ini menjadikan industri kreatif menjadi salah satu program unggulan dari pemerintah, berdirinya Bekraf merupakan inisiatif untuk mengakomodir industri ini. Payung hukum, untuk pendirian Bekraf adalah diterbitkannya Peraturan Presiden (Perpres) Nomor 6 Tahun 2015 tentang Badan Ekonomi Kreatif, pada 20 Januari 2015 (Gewati, 2019).

Dari sekian banyak pendapatan dari sektor ekonomi kreatif,subsektor fashion, kriya, dan kuliner menguasai $97 \%$ dari total usaha yang mencapai 8,2 juta unit (Fuad, 2018). Berdasarkan data statistik badan ekonomi kreatif tahun 2016, Provinsi Jawa Barat tercatat memiliki share Produk Domestik Regional Bruto (PDRB) terhadap PDB Ekonomi Kreatif sebesar 11,81 dan pada tahun 2016, Jawa Barat menempati urutan pertama dari 10 provinsi yang memiliki kontribusi ekspor ekonomi kreatif terbesar yaitu sebesar 31,96 persen. (Pemprov Jabar, 2019).

Bisnis digital merupakan salah satu bidang dalam ekonomi yang diminati pada saat ini. Banyak perusahaan yang sedang melakukan transisi atau bahkan sudah beralih dari bisnis konvensional menjadi bisnis digital. Hal ini dilakukan untuk memperluas market share perusahaan dalam bisnis mereka. Ditambah dengan adanya pandemi COVID-19 pada saat ini yang mengakibatkan beberapa pengusaha mulai mencari jalan untuk menjual produk mereka dikarenakan beberapa lini bisnis tidak dapat beroperasi secara maksimal jika secara offline. Dari beberapa kategori bisnis di Indonesia, Usaha Mikro, Kecil dan Menengah atau (UMKM) merupakan salah satu kategori bisnis yang mendapatkan dampak dari pandemi COVID-19, dikarenakan keuangan dari pelaku bisnis kategori UMKM beberapa bahkan belum stabil sebelum 
adanya pandemi COVID-19 dan makin diperparah dengan adanya pandemi tersebut.

Bisnis digital sendiri memiliki beberapa kekuatan dan kelemahan yang harus dicermati sebelum memulainya. Terdapat kekuatan bisnis digital untuk UMKM yaitu; Modal yang dikeluarkan relatif kecil dikarenakan tidak membutuhkan penyewaan tempat usaha; Jangkauan yang luas untuk semua kalangan dimanapun mereka berada; dan juga dapat dikerjakan kapan saja dan dimana saja. Kekurangannya sendiri yaitu adalah koneksi internet yang belum didapatkan oleh semua orang di Indonesia. Maka dari itu, pengusaha mulai mencoba merambah ke dunia bisnis digital untuk memperluas jaringan bisnisnya. Namun dengan adanya operasi bisnis digital sendiri akan mengakibatkan beberapa hambatan lainnya. Pada kasus ini, hambatan tersebut yaitu ketidakpahaman sebagian pelaku bisnis terhadap perkembangan bisnis digital mulai dari pembuatan bisnis digital dan pengoperasian bisnis digital.

Hal ini yang menggerakkan kami untuk membantu pelaku bisnis dengan cara mulai melakukan pergerakan di dalam dunia bisnis digital dengan bentuk program pembuatan platform untuk menjual yaitu marketplace dan on-demand multiservice platform. Kami berupaya untuk membantu bidang usaha food and beverage yang mana mendapatkan dampak dari anjuran pemerintah untuk berdiam dirumah guna memperlambat laju penyebaran COVID-19 mempengaruhi masyarakat untuk menghabiskan waktu dirumah yang mana akan berdampak pada usaha food and beverage. Dilansir dari Kontan.co.id, tercatat, Bali dan Surabaya mengalami penurunan sebesar $26 \%$ sedang masingmasing wilayah lainnya hanya $18 \%$ (Fadila, 2020).

Migrasi pola marketing lama ke marketing digital membutuhkan usaha yang tidak mudah, banyak pelaku industri ini, yang notabene masuk ke dalam kategori Usaha Mikro Kecil Menengah (UMKM), tidak punya cukup modal, baik secara finansial maupun sumber daya manusia, untuk melakukannya. Perpindahan ke marketing digital menjadi suatu keharusan, terutama digital creative marketing untuk memperkuat brand dan meningkatkan penjualan, hal ini didukung oleh (Nicholson, 2020) yang menyatakan bahwa:

With the shift to ecommerce now undoubtedly dominating the retail space, well-executed, creative marketing ideas are crucial in both raising awareness of your brand and driving sales (Nicholson, 2020)

Para pelaku UKM seharusnya juga sudah mulai memanfaatkan media digital sebagai salah satu upaya pemasaran produknya sehingga konsumen lebih mengenal produk yang dihasilkan oleh UKM tersebut. Salah satu platform media digital yang bisa digunakan oleh para UKM dalam meningkatkan pemasaran produknya adalah Instagram.Instagram sendiri merupakan aplikasi yang berbasis media seperti foto dan video yang disertai dengan deskripsi. Selain itu, Instagram juga menyediakan akun bisnis yang dapat menunjang kebutuhan pelaku UMKM. Salah satu pelaku UMKM di Bandung yang mencoba memanfaatkan Instagram untuk marketingnya adalah "Coffeestrip".

"Coffeestrip" ini awalnya bernama Esprenade. "Essprenade Brewerry" adalah UMKM Bandung yang berbasis produk olahan kopi. Essprenade sendiri adalah produk kopi olahan yang dibuat sendiri menggunakan konsentrat cold brew yang dicampur dengan lemon dan soda. Essprenade diproduksi sendiri dari dapur rumah mereka yang terletak di Padasuka, Bandung. Berdirinya Essprenade ini karena keingin mengubah sudut pandang orang dimana biasanya saat mendengar kopi pasti teringat dengan kopi susu yang dikenal dengan rasa pahitnya, sehingga mereka ingin membuat kopi yang tidak pahit dan bisa dikonsumsi semua orang. Dengan itu juga, yang menjadi slogan mereka yaitu \#bukankopisusu.

Target pemasaran Essprenade sebenarnya merupakan semua kalangan yang menyukai kopi, dengan range umur 10-60 tahun. Oleh sebab Essprenade aman dikonsumsi dari yang berumur 1060 tahun, sehingga untuk target customernya juga mereka terbuka untuk semua kalangan.Untuk saat ini, setelah perubahan namanya ke "Coffeestrip" mereka juga mempunyai produk lain selain Essprenade, produk tersebut yaitu Eskosu, dan Kopi Susu Mint.

Tujuan dari Pengabdian Kepada Masyarakat (PKM) ini yaitu untuk membantu bisnis UMKM Coffeestrip melalui sosial media planning serta pembuatan media platform marketplace (Shopee) dan on-demand multi-service platform (Gojek) untuk meningkatkan penjualan dari bisnis UMKM tersebut. Pembuatan media platform ini ditujukan untuk menambahkan cara berbisnis yang lebih bersaing, kompeten dan memperluas jaringan bisnis dari pelaku UMKM.

Manfaat dari artikel ini adalah sebagai referensi untuk UMKM agar mengetahui alur pembuatan konten media sosial serta platform marketplace dan on-demand multi-service platform. Selain itu sebagai referensi untuk UMKM untuk mengetahui lebih banyak tentang bisnis digital.

\section{METODE}

KKN-PPM yang berjudul "Digital Marketing Untuk UMKM di Bandung: Studi Kasus pada Coffeestrip di Bandung" ini dilakukan secara virtual atau daring menggunakan media komunikasi online 
dari rumah masing masing.Media komunikasi yang digunakan melalui aplikasi google meet, whatsapp dan line. Aplikasi yang digunakan untuk mengerjakan tugas bersama antara anggota kelompok melalui trello dan google classroom.Setiap anggota memiliki tugas yang berbeda-beda secara adil dan pembagiannya dilakukan pada media komunikasi yang kami gunakan.

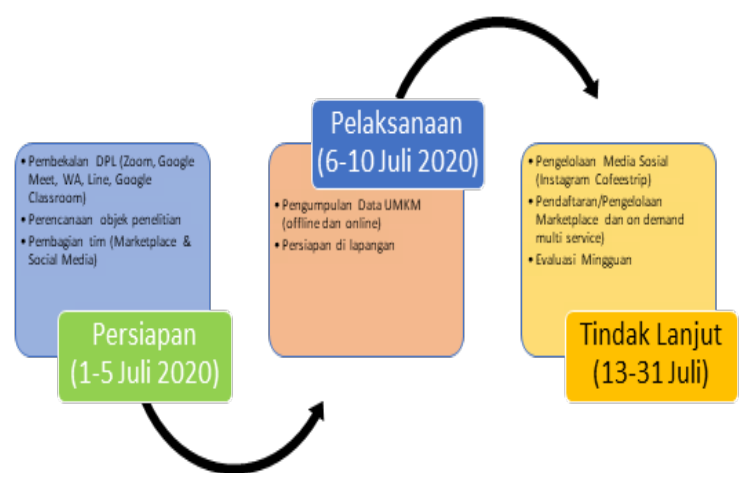

Gambar 1. Metode pelaksanaan KKN-PPM

Dalam mendiskusikan kegiatan ini secara lebih jelas, terdapat beberapa anggota kelompok yang melakukan pertemuan dengan owner dari UMKM "Coffeestrip" secara langsung di Bandung. Anggota kelompok yang bertemu dengan pihak owner bertempat tinggal tidak jauh dengan pemilik owner sehingga dapat bertemu langsung dengan tetap menerapkan protokol kesehatan selama pertemuan berlangsung.Dengan adanya perwakilan kelompok yang bertemu dengan owner, secara langsung memudahkan kami untuk mendapatkan informasi yang lebih jelas mengenai usahanya yang akan kami bantu dalam KKN ini sehingga dapat mempermudah pengerjaannya. Subjek dari kegiatan ini adalah owner pemilih UMKM "Coffeestrip", sedangkan objek dari kegiatan ini adalah produk dari "Coffeestrip" yang akan dibantu dalam pemasarannya. Lokasi kegiatan yaitu di daerah masing-masing atau lebih tepatnya di kediaman masing-masing mahasiswa, sedangkan lokasi yang dijadikan objek (UMKM) kegiatan KKN-PPM Integratif Virtual yaitu di daerah Padasuka,Bandung. Waktu kegiatan ini selama 1 bulan yang dimulai dari tanggal 1 Juli 2020 sampai dengan 31 Juli 2020.

Tahapan pelaksanaan PPM KKN Integratif terdiri dari tahap persiapan, pelaksanaan dan tindak lanjut. Berikut uraian tahapan pelaksanaan yang dilakukan:

\section{- Tahap Persiapan}

Pada tahap ini, diberikannya pembekalan oleh DPL mengenai pelaksanaan kegiatan KKN-PPM, pemilihan UMKM yang menjadi objek, pemilihan ketua kelompok dan koordinasi antara mahasiswa dan DPL untuk merancang kegiatan apa yang akan dilakukan saat tahap pelaksanaan. Dari hasil diskusi terbagi menjadi 2 kelompok kecil yaitu kelompok marketplace dan sosial media planning (koordinator, design, foto produk dan copywriter), kemudian mahasiswa melakukan diskusi secara mandiri untuk pembagian tugas masing-masing anggota secara adil dan disepakati oleh bersama. Setelah itu kami menyampaikan rancangan kegiatan yang akan kami lakukan pada DPL dan owner UMKM "Coffeestrip" yang menggambarkan penjelasan mengenai kegiatan yang akan kami lakukan. Selain itu mahasiswa juga mulai membuat rancangan untuk sosial media dari UMKM tersebut.

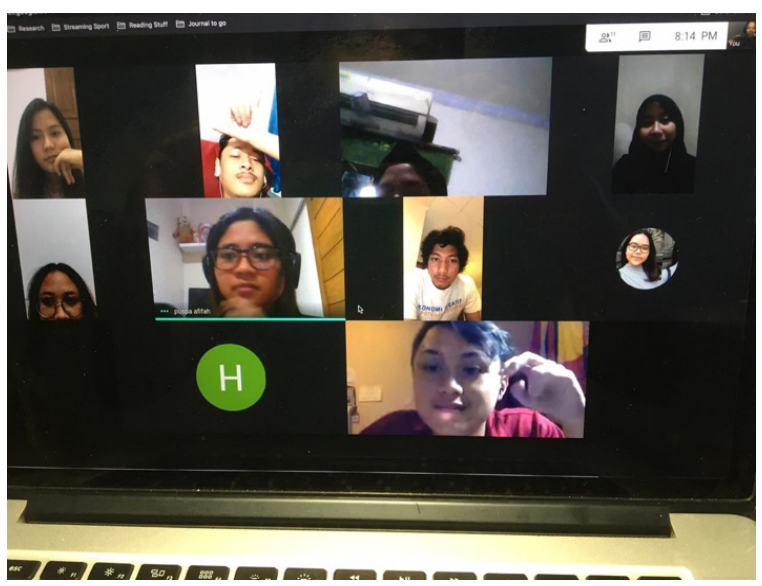

Gambar 2. Tahap Awal Pembekalan KKN-PPM melalui Google Meet

- Tahap Pelaksanaan (tanggal 6-10 Juli),

Terdiri atas pengumpulan data, penyiapan lapangan, pelaksanaan kegiatan pengabdian kepada masyarakat, dan tindak lanjut. Pengampu kegiatan KKN-PPM dan mahasiswa peserta KKN-PPM berdiskusi serta memilih UMKM apa yang akan dijadikan sebagai media pelaksanaan KKN-PPM kewirausahaan. Setelah UMKM terpilih, mahasiswa berdiskusi bersama pemilik UMKM mengenai latar belakang, ide, dan konsep dari UMKM. Pada tahap ini kami melakukan kegiatan pengumpulan data dari owner, merancang konsep dan mulai mengerjakan tugas masing-masing yang sudah ditentukan sebelumnya. Dimana masing-masing bagian, koordinator yang bekerja mengoordinir seluruh kegiatan baik sosial media maupun marketplace, tim design yang membuat design untuk konten postingan di Instagram maupun marketpclace, tim foto produk yang membuat foto dan video produk dan tim copywriter yang membuat konten postingan dan caption produk di media sosial Instagram. Pelaksanaan kegiatan KKN-PPM dilakukan secara daring, dan apabila diperlukan maka berdiskusi tatap muka diperbolehkan dengan tetap mengikuti protokol kesehatan. Masing-masing kelompok melakukan riset mengenai tugasnya masing-masing dan mengumpulkan data dengan berdiskusi mandiri dengan pemilik UMKM. 


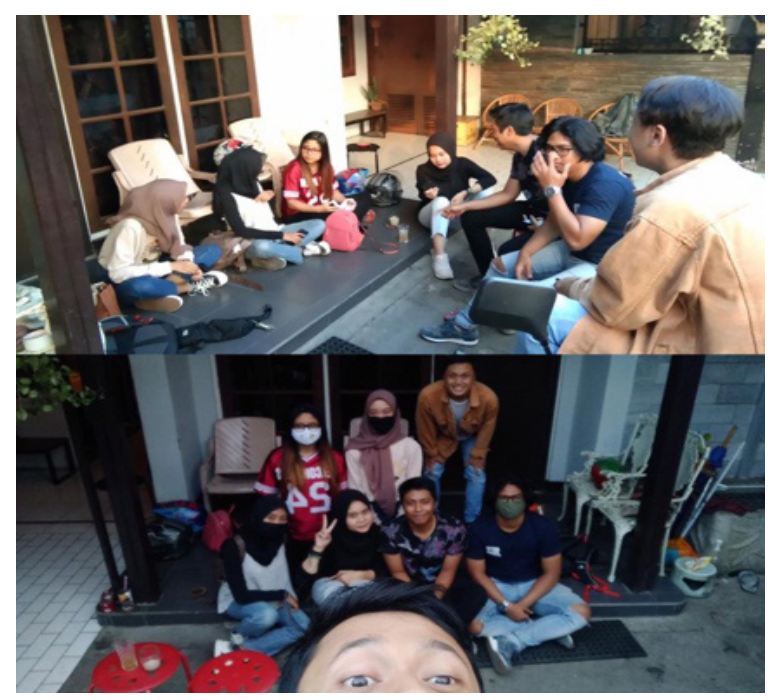

Gambar 3. Rapat offline dengan owner membahas data Coffeestrip

- Tahap Tindak Lanjut (tanggal 13-31 Juli 2020),

Yang dilakukan adalah berkoordinasi antara semua tim untuk memulai mengelola Instagram dari UMKM "Coffeestrip" tersebut dengan mempublikasikan seluruh hasil kami baik foto, design dan caption yang telah disiapkan. Koordinasi dan konsultasi tim dilakukan kembali setelah semua data terkumpul. Data yang telah didapat lalu di-input dan diolah. Mahasiswa KKN-PPM juga memberikan follow up kegiatan yang telah dilakukan kepada pemilik UMKM tiap minggunya, serta meminta evaluasi dari pemilik UMKM terhadap apa yang telah dikerjakan oleh mahasiswa KKN-PPM agar hasil yang didapat memuaskan serta sesuai yang diharapkan oleh pemilik UMKM.

\section{HASIL DAN PEMBAHASAN}

Secara mendetail kegiatan pengabdian kepada masyarakat ini terbagi atas dua kegiatan yaitu menangani media sosial dan marketplace.

\section{Media Sosial Coffeestrip}

Tujuan utamanya adalah meningkatkan brand awareness dari merek "Coffeestrip" dengan perombakan media sosial Instagram milik Coffeestrip dan juga mendaftarkan "Coffeestrip" ke beberapa marketplace seperti Go-food dan Shopee. Tujuan dalam meningkatkan brand awareness dan juga insight "Coffeestrip" di media social Instagram adalah peningkatan kesadaran masyarakat akan merek kopi baru yaitu "Coffeestrip",sehingga merek ini dapat dikenal lebih banyak masyarakat dan dapat membantu industri lokal.

Program kegiatan ini diawali dengann tahap perencanaan awal, serta pengonsepan tentang apa saja yang akan dilakukan untuk menumbuhkan konten bagi media sosial Instagram "Coffeestrip" yang. Setelah itu dilakukan proses desain grafis, copywriting, dan juga foto produk sebagai aspekaspek yang perlu dipenuhi untuk menciptakan suatu konten yang menarik.Setelah semua aspek selesai, seluruh aspek tersebut digabungkan menjadi beberapa post Instagram yang akhirnya akan dipost di Instagram "Coffeestrip". Hasil yang diperoleh dari kegiatan $\mathrm{KKN}$ ini adalah terisinya konten di feeds Instagram "Coffeestrip" dan juga naiknya insight di Instagram "Coffeestrip". Sayangnya untuk marketplace seperti Go-food dan juga Shopee belum tercapai, dikarenakan butuh waktu yang cukup lama untuk mendapatkan verifikasi dari kedua pihak tersebut. Untuk kedepannya, tim memberikan pembekalan kepada pihak "Coffeestrip" berupa foto produk yang nantinya bisa digunakan untuk konten "Coffeestrip" pribadi, selain itu juga diharapkan proses verifikasi Shopee dan Go-food dapat terselesaikan.

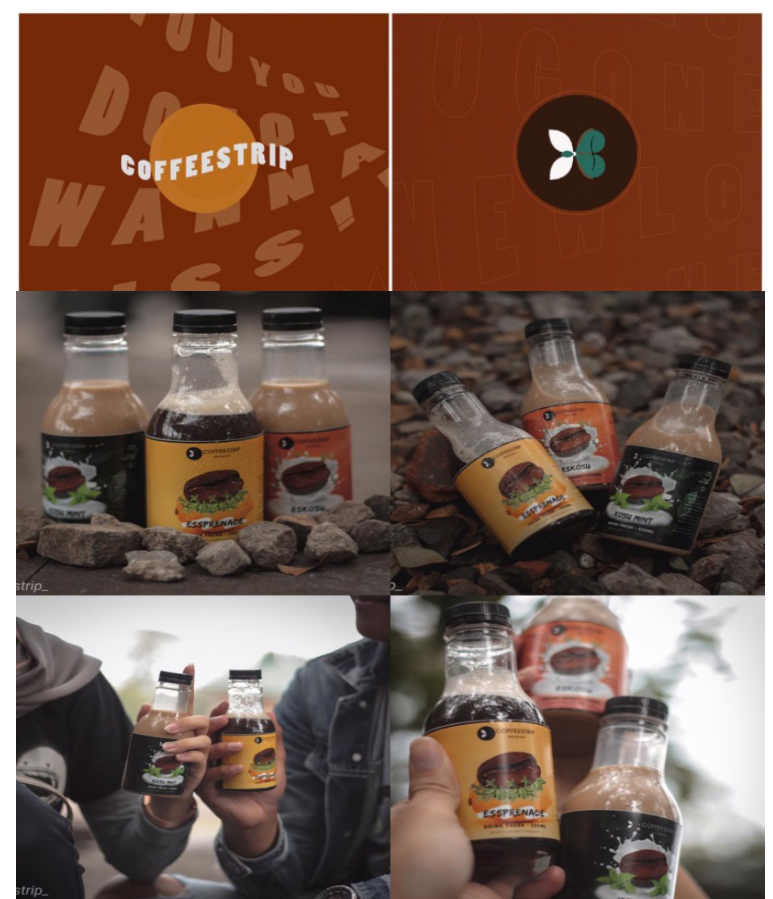

Gambar 4. Logo dan foto produk Coffeestrip

Selama satu bulan, kelompok KKN-PPM Integratif dengan topik "Digital Marketing untuk UMKM di Bandung" telah bekerja sama membantu UMKM terkait, yaitu "Coffeestrip", dalam memasarkan produknya dan memperkenalkan merek dagangnya pada masyarakat yang cakupannya lebih luas melalui pemasaran digital. Dalam prosesnya, setiap individu dalam kelompok memiliki tugasnya masing-masing. Tugas-tugas tersebut terbagi ke dalam tim desainer grafis, fotografer, copywriter, dan juga manajemen toko daring. Capaian yang sudah terpenuhi yaitu terisinya konten di Instagram "Coffeestrip" dengan desain grafis yang segar dan tone of voice yang sesuai dengan target pasar, yaitu 
usia 15 tahun sampai dengan 35 tahun, melalui copywriting yang bersifat santai. Sebelumnya, "Coffeestrip" belum menemukan tone of voice atau brand's voice yang sesuai karena target pasarnya yang belum spesifik. Selain itu, tim fotografer dan desain grafis juga membantu untuk membuat tampilan produk yang menarik bakal calon konsumen dengan foto-foto yang terlihat profesional dan grafis dengan perpaduan warna yang pas. Peningkatan yang diperoleh sejauh ini adalah naiknya kunjungan ke profil Instagram "Coffeestrip". Namun terdapat hal yang disayangkan yaitu belum tersedianya produk-produk "Coffeestrip" di toko daring Shopee dan GoFood milik Gojek karena prosesnya yang memakan waktu lama.

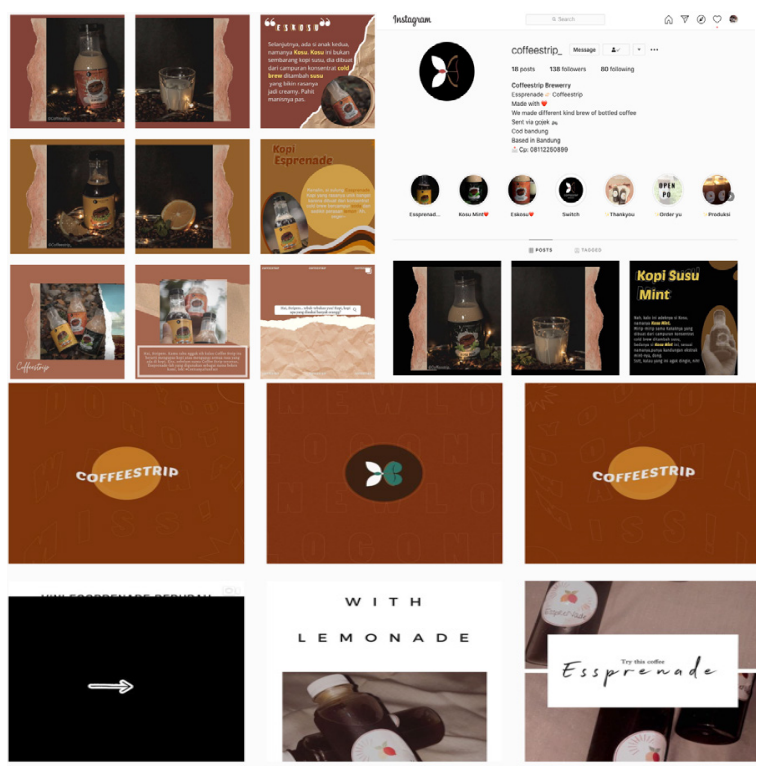

Gambar 6. Hasil Posting di akun Instagram Coffeestrip

Dalam upaya tindak lanjut KKN-PPM Integratif dengan topik "Digital Marketing untuk UMKM di Bandung", kami telah membekali "Coffeestrip" dengan banyak stok foto yang dapat digunakan untuk konten-konten yang akan datang. Baik itu untuk penggunaan di Instagram, Shopee, maupun GoFood. Sehubungan dengan itu, penyelesaian proses verifikasi Shopee dan GoFood masuk ke dalam rencana tindak lanjut kelompok kami walaupun kegiatan KKN-PPM Integratif ini sudah selesai.

\section{Marketplace dan Go-Food}

Coffeestrip telah berhasil terdaftar di Shopee dan Go-Food. Pada akun Shopee, setelah berhasil terdaftar dilakukan pemasangan produk Coffeestrip. Shopee memiliki kelebihan yaitu dapat melakukan pengiriman ke seluruh penjuru Indonesia. Namun, mengikuti permintaan pemilik yang masih khawatir dalam pengiriman antar kota disebabkan produk Coffeestrip merupakan produk kopi kemasan, maka untuk penjualan di Shopee dibatasi hanya untuk daerah Cimahi, Bandung, dan Jatinangor, dengan jasa pengiriman Go-Jek. Kelebihan lainnya adalah Shopee memiliki berbagai macam program promo yang dapat dinikmati pembeli, seperti program 'Gratis Ongkir' dimana pembeli dapat menikmati gratis ongkos kirim hingga dua puluh ribu, yang tentu akan meningkatkan minat pembeli. Akan tetapi, pendaftaran program 'Gratis Ongkir' memerlukan foto KTP bersama pemilik, sehingga untuk saat ini program tersebut belum dapat dinikmati. Fitur lain yang ada di Shopee juga adalah penaikkan produk, dimana produk akan berada di halaman teratas pencarian sehingga akan lebih banyak pengguna Shopee yang dapat melihat produk yang dijual. Penaikkan produk dapat dilakukan tiap 4 jam sekali. Berdasarkan hasil pantauan akun Shopee selama 2 minggu, terdapat rata-rata 4 views pada 3 produk Coffeestrip. Sedikitnya views kemungkinan disebabkan sedikitnya orang yang membeli produk minuman di Shopee. Meski demikian, penjualan di Shopee memiliki potensial yang besar, melihat Coffeestrip memiliki Instagram dimana link Shopee dapat dicantumkan di deskripsi akun Instagram Coffeestrip sehingga pembeli di Instagram dapat membeli produk Coffeestrip dengan mudah dengan cara meng-klik link Shopee yang tertera di bagian deskripsi.

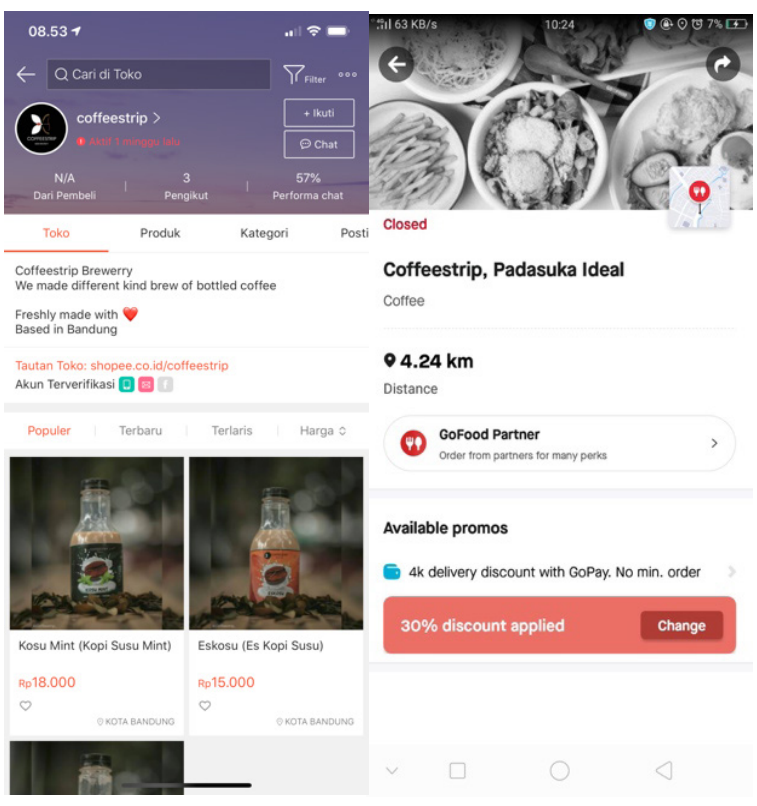

Gambar 7. Akun Coffeestrip di market place shopee, dan di aplikasi Go-Food

Pada akun Go-Food, Coffeestrip telah berhasil terdaftar. Namun, untuk pemasangan produk terdapat kendala yaitu diperlukannya aplikasi Go-Biz yang hanya dapat diinstal di android, sedangkan kedua pemilik Coffeestrip merupakan pengguna iPhone. Hal ini menjadikan sulit untuk memasangkan produk di Go-Food karena pesanan akan masuk melalui aplikasi Go-Biz sehingga aplikasi tersebut harus dipegang oleh pemilik Coffeestrip. Meskipun 
begitu, pemilik Coffeestrip sedang mengusahakan agar mereka dapat mengakses aplikasi Go-Biz, dilihat dari marketplace Go-Food yang sangat menjanjikan pasarnya karena Go-Food banyak dikenal dan digunakan untuk pemesanan makanan dan minuman. Dengan belum terpasangnya produk Coffeestrip di Go-Food, maka untuk sekarang penjualan dilakukan melewati Go-Send, Shopee, dan pengiriman langsung (COD) untuk daerah Bandung.

\section{SIMPULAN}

UMKM merupakan sektor yang vital bagi perekonomian Indonesia karena menjadi penyumbang PDB terbesar dan juga menyerap banyak tenaga kerja, oleh karena itu perekonomian Indonesia sangat dipengaruhi oleh UMKM. Saat ini industri sedang mengalami perubahan ke arah digital karena adanya revolusi teknologi informasi yang mengakibatkan pemasaran dari sebuah usaha berubah yang pada mulanya masih berbentuk tradisional dan konvensional menjadi digital, pemasaran secara digital atau yang biasa disebut digital marketing bisa dimanfaatkan oleh pelaku UMKM agar bisa mendapatkan konsumen yang lebih luas lagi dan memperbanyak penjualan produk mereka. Dengan begitu pada kegiatan KKNPPM Integratif ini mendorong UMKM agar bisa tetap beraktifitas secara digital dengan membantu digital marketing untuk UMKM di Bandung bernama "Coffeestrip". "Coffeestrip" sendiri adalah UMKM yang menjual produk olahan kopi dan terletak di Padasuka, Bandung. Kegiatan yang kami lakukan untuk digital marketing "Coffeestrip" adalah membantu dalam perombakan dan perapihan laman Instagram mereka dan membantu mereka agar produk "Coffeestrip" bisa dijual di Go-food dan Shopee. Dalam kegiatan digital marketing yang kami lakukan terdapat dua sub kelompok yaitu social media planning dan marketplace

Rekomendasi dalam artikel ini adalah UMKM harus mendapatkan bantuan dalam memfokuskan pada revolusi industri komunikasi sehingga penjualan online bisa menjangkau konsumen lebih luas dan banyak, terlebih lagi dengan adanya pandemi COVID-19 yang berlangsung membuat pengguna internet menjadi naik dari sebelumnya, sehingga dalam momen ini setelah kami membantu "Coffeestrip" dalam digital marketing-nya alangkah lebih baik jika "Coffeestrip" terus melakukan digital marketing agar usahanya bisa berkembang dan memiliki penjualan yang baik.

\section{DAFTAR PUSTAKA}

Fadila, A. (2020). Industri food \& beverage ikut terdampak wabah virus corona. Retrieved from https://industri.kontan.co.id/news/industrifood-beverage-ikut-terdampak-wabah-viruscorona

Fuad, H. (2018). Pendapatan Ekonomi Kreatif Diprediksi Tembus Rp.1.200 Triliun di 2019. Retrieved from https://economy.okezone.com/ $\mathrm{read} / 2018 / 12 / 20 / 320 / 1993774 /$ pendapatanekonomi-kreatif-diprediksi-tembus-rp1-200triliun-di-2019?page $=2 \% 0 \mathrm{D} \% 0 \mathrm{~A} \% 0 \mathrm{D} \% 0 \mathrm{~A}$

Gewati, M. (2019). Tumbuh Pesat, Jokowi Optimis Industri Kreatif Jadi Kekuatan Indonesia. Retrieved from https://money.kompas.com/ $\mathrm{read} / 2019 / 03 / 21 / 082000826 /$ tumbuh-pesatjokowi-optimis-industri-kreatif-jadi-kekuatanindonesia?page $=$ all

Nicholson, L. (2020). Creative Digital Marketing Strategies for The Retail Sector That Really Work. Retrieved February 25, 2020, from https://www.hitsearchlimited.com/news/ creative-digital-marketing-strategies-for-theretail-sector-that-really-work

Pemprov Jabar. (2019). Potensi Industri Kreatif Jabar Sangat Tinggi. Retrieved February 15, 2020, from https:/www.jabarprov.go.id/index.php/ news/33952/2019/08/06/Potensi-IndustriKreatif-Jabar-Sangat-Tinggi 